JÓZEF FISZER

Instytut Studiów Politycznych PAN, Warszawa

DOI : $10.14746 /$ rie.2016.10.4

\title{
Unia Europejska dziś i jej niepewna przyszłość. Część II
}

Podobnie jak na temat Rosji i jej perspektyw, również na temat Unii Europejskiej i jej przyszłości, szans i zagrożeń mamy różne scenariusze i rozbieżne opinie tak wśród elit politycznych, jak i zwykłych obywateli. Szczególne kontrowersje wzbudza UE w latach 2004-2014, czyli miniona dekada od jej rozszerzenia na Wschód. Kraje „starej Unii” głoszą dziś, że rozszerzenie w 2004 roku UE na Wschód było błędem, gdyż było przedwczesne i dla nich bardzo kosztowne (Koszel, 2012, s. 104). Natomiast ,nowe” kraje unijne z Europy Środkowo-Wschodniej mają pretensje, że w UE traktowane są po macoszemu i nadmiernie wykorzystywane przez kraje „starej UE”. Jest to efekt niewiedzy i zbyt mocno wygórowanych nadziei, jakie wiązano w krajach Europy Środkowo-Wschodniej, także w Polsce z akcesją do Unii Europejskiej. Jak potwierdzają to badania naukowe prowadzone przez socjologów, psychologów, prawników i politologów, chcemy Unii silnej i efektywnej pod każdym względem, Unii, która będzie gwarantem naszych interesów narodowych w Europie i na świecie, a z drugiej strony boimy się UE, którą ,rządzi niemiecko-francuski tandem”, dbający o zachowanie suwerenności swoich państw, a zarazem zmuszający do rezygnacji z niej pozostałe państwa członkowskie. De facto, mamy dziś w Polsce i w innych krajach Europy Środkowo-Wschodniej dwie opcje, dwa spojrzenia na Unię Europejską i na efekty po dziesięciu latach członkostwa w UE: pozytywne i negatywne, determinowane przynależnością partyjną (polityczną) i wyznawaną aksjologią. Z jednej strony akceptuje się tę organizację i wskazuje na potrzeby włączenia w jej decyzyjny mainstrem oraz podkreśla się pozytywny bilans członkostwa w Unii, a z drugiej strony pokazuje niebezpieczeństwa i zagrożenia płynące z Brukseli oraz eksponuje negatywne skutki dla Polski i pozostałych państw członkowskich z Europy Środkowo-Wschodniej. W związku z tym, chce się pogłębiania integracji i wzmocnienia UE, albo odwrotnie, postuluje się ją politycznie i ideologicznie rozmiękczyć, rozluźnić, tak zmienić, aby de facto przekształciła się w jakieś niezobowiązujące stowarzyszenie suwerennych państw, strzegące swych granic przed napływem imigrantów (Fiszer, 2014, s. 29-59).

Problemy imigrantów w UE, ich akulturacji oraz związane z tym takie zjawiska i procesy społeczne, jak ksenofobia i nacjonalizm, potęguje też nasilający się po 2001 roku w Europie i na świecie terroryzm międzynarodowy, zwłaszcza terroryzm determinowany przez islamskich fundamentalistów (Fiszer, Olszewski, 2013, s. 267-295). Terroryzm jest zjawiskiem historycznie zmiennym, ciagle ewoluującym, wielopłaszczyznowym i wieloaspektowym, dynamicznym, występującym w różnych postaciach. Zmienia się pod wpływem rozwoju cywilizacyjnego, a zwłaszcza postępu naukowo- 
technicznego. Terroryści umiejętnie wykorzystują nowoczesne środki łączności, mass media, nowoczesne techniki komunikowania się i wywierania wpływu na społeczeństwo. Dlatego z trudnością poddaje się jednoznacznemu zdefiniowaniu, a w rezultacie tego jest niezwykle trudno go zwalczać. Tym bardziej, że popiera go wiele państw lub grup etnicznych (narodowych), dążących do posiadania własnego państwa. Terroryzm, który nasila się od początku XXI, przybiera zarazem bardzo niebezpieczne formy dla współczesnego świata i wzbudza coraz większy niepokój wśród elit politycznych, ludzi nauki, kultury i publicystów. Zdominowany przez ekstremistyczny islamski fundamentalizm, prowadzi wręcz do zderzenia cywilizacji i kultur, a tym samym do głębokich podziałów i konfliktów między państwami i narodami. Jak podkreśla Stanisław Koziej: „Nowe pokolenie terrorystów nie walczy o Irak, Afganistan czy Palestynę, poszczególnym zamachom i groźbą nie towarzyszą żądania zwolnienia więźniów czy zmiany określonego fragmentu polityki poszczególnych państw. Odrzucając nacjonalizm, nowi terroryści chcą zburzyć istniejący porządek świata i ustanowić globalną wspólnotę wiernych" (Koziej, 2006, s. 37; Tibi, 1997; Borkowski, 2006). W tym też celu, wykorzystując chaos w Iraku, Libii i Syrii, do którego przyczyniły się Stany Zjednoczone poprzez próbę eksportu demokracji do krajów arabskich, islamscy fundamentaliści utworzyli pod koniec 2014 roku na pograniczu Syrii i Iraku Państwo Islamskie, które stanowi poważne zagrożenie dla Unii Europejskiej i całego Zachodu, gdzie codziennie przybywają tysiące imigrantów z Północnej Afryki i Bliskiego Wschodu, uciekających przed islamskim fanatyzmem.

Dlatego też dziś islam napawa mieszkańców Zachodu nie tyle ciekawością, ile niepokojem i obawami o własne bezpieczeństwo i przyszłość świata. Obawa świata przed agresywnym islamem jest - w obliczu narastającej aktywności terroryzmu fundamentalistów zrozumiała, jednak z punktu widzenia pełnej o nim wiedzy nie do końca racjonalna. Strach przed islamem ma dwa źródła: 1) w tradycji dżihadu, czyli obowiązku muzułmanina dokonywania wszelkiego możliwego wysiłku na rzecz islamizacji świata. Marzeniem wiernego jest bowiem doczekanie przekształcenia się całej kuli ziemskiej w jeden kalifat; 2) we współczesnej eksplozji islamskiego gniewu (terroryzmu), skierowanego przeciwko niewiernym wszelkiego rodzaju - od Europejczyków, przez Amerykanów, Rosjan, Żydów i Hindusów po własnych, niedostatecznie fundamentalnych współplemieńców. Ten gniew, będący efektem frustracji i tęsknoty za utraconą potęgą, jaką w przeszłości była cywilizacja islamska, realizuje się przez ślepe ataki na przypadkowych ludzi, obiekty cywilne i wojskowe oraz jednoczesną dbałość o spektakularne ukazywanie zamierzonego barbarzyństwa w światowych mediach.

Muzułmanie mają świadomość gospodarczej słabości i z tą świadomością nie potrafią sobie dać rady. Tęsknota za minionym Złotym Wiekiem miesza się z poczuciem niemożności uporania się z problemami w rozsądnym czasie. Fakt, że żyją i mieszkają w regionie, który niegdyś wytworzył system uważany za idealny oraz przekonanie, że lepszego nie ma i być nie może, ściera się tu z kompleksem niższości mającym źródło w poczuciu zacofania, ubóstwa, niskiego poziomu edukacji i fatalnej opinii w świecie. Kraje islamu, w szczególności zaś kraje arabskie, należą do państw o najniższych wskaźnikach umiejętności czytania i pisania oraz - poza pewnymi wyjątkami - są w większości opóźnione w rozwoju gospodarczym i naukowo-technicznym (Sardar, 
Davies, 2005; Danecki, 2002; Dziekan, 2007; Jordan, 2004; Krawczyk, 2009; Lewandowski, 2008; Mendel, 2010).

Terroryzm jest militarną twarzą tych nurtów islamu, które pragną przywrócić go w jego najczystszej formie, w nadziei, że razem z nim przywrócona zostanie imperialna pozycja muzułmanów utracona przed pięciuset laty. Fundamentaliści islamscy i ich intelektualiści lansują wśród muzułmanów ideologię obiecującą im panowanie nad światem. Jak każda tego typu ideologia niepoparta sukcesami gospodarczymi jest oczywistą iluzją, ale iluzją groźną, bo skłaniającą do popełniania aktów ślepego terroru, nie szczędząc przy tym własnego życia w nadziei na korzyści, jakie islam przy tej okazji obiecuje swoim męczennikom.

Wybitny intelektualista, filozof i socjolog Joseph H. H. Weiler trafnie zauważa, że: „Idea integracji europejskiej nie funkcjonuje dziś w dyskursie publicznym tak jak kiedyś. Politolodzy ze szkoły realistycznej niestrudzenie powtarzają nam, że siłą napędową integracji były egoizmy narodowe oraz chłonny rynek zysków i kosztów ze strony poszczególnych państw członkowskich, które uczestniczyły w tym procesie. Ale w okresie założycielskim, a nawet dłuższą chwilę później sama idea Wspólnota była kojarzona z pewnym zestawieniem wartości, które, jak sądzę, miały działać na wyobraźnię, uruchamiać siły polityczne o rozległym poparciu, a także stawiać opór potężnemu, lecz często nadużywanemu urokowi nacjonalizmu. Popierać Wspólnotę znaczyło wówczas ,robić to, co należy”. Był to pewien szczęśliwy okres, kiedy można było wierzyć, że interes i wyższe wartości na dłuższą metę są ze sobą zgodne. To jak opinia publiczna przyjęła traktat z Maastricht, jest dla nas ostrzeżeniem: ,czyżby ustanowiona w Maastricht Europa była ideałem, który utracił siłę napędową? A może siłę, która utraciła swój napędowy ideał? Musimy zatem wyzbyć się złudzeń i zmierzyć się z celami integracji europejskiej, które często bywają zaniedbywane, ponieważ rzeczą pilniejszą wydaje się dyskusja o środkach - narzędziach i mechanizmach o charakterze politycznym i gospodarczym, pozwalających realizować konkretne, określone w traktatach zadania" (Weiler, 2007, s. 18-19).

Zatem dziś trzeba wrócić do rozważań nad ideałami integracji i celami UE w XXI wieku, jeśli ma ona przetrwać i stać się fundamentem dla przyszłej Europy i umocnić jej pozycję w powstającym nowym systemie międzynarodowym. Zwrócił na to uwagę również papież Franciszek w swoich przemówieniach wygłoszonych 24 listopada 2014 roku w Parlamencie Europejskim i w Radzie Europy, chwaląc Europę za rangę, jaką nadaje prawom człowieka, a zarazem wytykając jej niesprawiedliwość społeczną i traktowanie ludzi jak przedmioty, w kontekście trudności, jakie dziś przeżywa europejska gospodarka i generowanych przez nią niesprawiedliwościach, które szczególnie dotykają młodych ludzi. Mówił też o pokoleniu licznych bezrobotnych, narastaniu populizmów oraz zagrożeniach dla pokoju w Europie i nieodległych od niej regionach. Papież Franciszek przypomniał też o chrześcijańskich korzeniach Europy i nawiązał do wizyty Jana Pawła II dwadzieścia sześć lat temu (w 1988 r.) w instytucjach europejskich i wygłoszonego wówczas przemówienia, w którym domagał się, by Europa 
mogła oddychać swoimi obydwoma płucami: zachodnim i wschodnim. Dodał, że dzisiejsza UE jest wprawdzie „obszerniejsza” i ma większe wpływy, ale towarzyszy jej „wizerunek Europy trochę podstarzałej i przytłumionej”. Papież Franciszek potwierdził, że Kościół widzi dobro w integracji europejskiej i chce odnowienia integrującej się Europy. Wielkie idee, które kiedyś inspirowały Europę - jak się wydaje - straciły dziś atrakcyjność - mówił z troską papież Franciszek. Mówił też z niepokojem o narastającym w Unii ,egoizmie i obojętności wobec najsłabszych oraz o unijnych instytucjach tracących zaufanie obywateli. Dał też do zrozumienia, że odrodzenie jest możliwe, ale „wspólne budowanie Europy nie może się obracać tylko wokół gospodarki” i „nie można się godzić, by Morze Śródziemne było wielkim cmentarzem” dla imigrantów, tonących w drodze na Stary Kontynent (Bielecki, 2014, s. 2; Moszyński, 2014, s. 17).

Cytowany już J. H. H. Weiler jest także optymistą i w przeciwieństwie do wielu innych europesymistów, a także badaczy i ekspertów uważa, że: „Wspólnota nie jest skazana na zagładę; nie jest nawet ciężko ranna. W swojej historii pokazała już, że umie przezwyciężać kryzysy. Bądź co bądź kryzys zawsze świadczył o jej żywotności i o tym, że jest potrzebna. Było by jednak lepiej dla Europy, gdyby aktualna debata o jej przyszłości dotyczyła nie tylko środków, ale również celów" (Weiler, 2007, s. 19).

Do tych „wielu innych badaczy i ekspertów”, zajmujących realistyczne, a zarazem pesymistyczne stanowisko odnośnie integracji, UE i jej przyszłości należy m.in. historyk i politolog brytyjski Timothy Garton Ash, który uważa, że Unia Europejska, a w ślad za nią cała Europa znajduje się dziś w wielkim kryzysie, i to nie tylko finansowo-gospodarczym. Pisze on, że: „Integrację europejską trafnie opisywano jako projekt elit, jednak europejskie narody miały podobne wspomnienia. Kiedy projekt szwankował (a działo się to wielokrotnie) reakcją elit było poszukiwanie jakiejś drogi do przodu, bez względu na trudność. Aż do lat dziewięćdziesiątych XX wieku, kiedy zaczął się upowszechniać zwyczaj organizowania narodowych referendów, Europejczyków rzadko pytano o to, czy zgadzają się z proponowanymi rozwiązaniami, choć - z drugiej strony - mogli też od czasu do czasu odwoływać wyborczą kartką z urzędu polityków odpowiedzialnych za ich wprowadzenie. Tak, czy inaczej, można powiedzieć, że przez czterdzieści lat projekt europejskiej unifikacji mógł liczyć na bierne przynajmniej wspieranie większości opinii publicznej w krajach kontynentu. [...] W projekcie tym jednak coś się popsuło już wkrótce po upadku muru berlińskiego - gdy europejscy przywódcy pośpiesznie obrali kurs na strukturalnie wadliwą unię walutową. Kiedy kolejne rządy, firmy i gospodarstwa domowe zadłużały się na potęgę, dla młodych Europejczyków od Portugalii po Estonię i od Finlandii po Grecję pokój, wolność, dobrobyt i socjalne bezpieczeństwo stały się czymś naturalnym. Kiedy bańka pękła, wielu gorzko się rozczarowało, a doświadczenia różnych narodów zaczęły boleśnie różnić się od siebie. Dziś kryzys wciąż nie został zażegnany, ale Europie w większości zabrakło motywacji, która niegdyś popychała ją ku jedności. Nawet jeśli wspólny strach przed skutkami rozpadu eurostrefy wciąż pozwala uniknąć najgorszego, Europa potrzebuje czegoś więcej niż tylko strachu, by znów stać się magnesem przyciagającym wszystkich, jakim była przez pół stulecia" (Ash, 2012, s. 10-11).

Czym jednak ma być to „coś więcej”, albo inaczej, czego dziś potrzebuje UE, aby mogła trwać, rozwijać się pod każdym względem i odgrywać ważną rolę na arenie 
międzynarodowej, rolę pierwszoplanowego aktora, z którego zdaniem będą liczyły się inne podmioty, m.in. Stany Zjednoczone i Rosja? Odpowiedź na tak postawione pytania nie jest łatwa, ale postaram się to uczynić w dalszej części niniejszego opracowania. T. G. Ash lansuje tezę, że Unia Europejska pozostaje dziś zamknięta w dysfunkcjonalnym trójkącie złożonym z polityki narodowej, polityki europejskiej i globalnych rynków, a ważne dla niej decyzje podejmują przywódcy państw członkowskich na zasadzie dobijania targu za zamkniętymi drzwiami w Brukseli, którzy biorą pod uwagę nie dobro i przyszłość całej Unii, lecz wyłącznie politykę i media we własnych krajach. Ponadto słabości i mankamenty dzisiejszej UE upatruje on w tym, że wciąż de facto nie ma prawdziwie europejskiej polityki i nie istnieje żadna szeroka europejska sfera publiczna (Ash, 2012, s. 15).

Unia Europejska potrzebuje nie tylko unii bankowej i fiskalnej, ale pilnie potrzebuje unii politycznej oraz umocnienia solidarności między jej obywatelami, na której będzie mogła się oprzeć, a także pewnej dozy europejskiego patriotyzmu, którego wciąż nie ma, natomiast szybko narastają frustracja, egoizm, narodowe i etniczne partykularyzmy oraz coraz głębsze podziały na Wschód i Zachód, Północ i Południe. W tym kontekście można się zgodzić z tezą T. G. Asha, że: ,[...] największym problemem europejskiego projektu jest jego sukces. W ciagu ostatnich dziesięciu lat europejskie narody dotąd obarczone kompleksami z powodu przypisywanego im peryferyjnego statusu, poczuły, że w końcu stają się częścią centrum. Europejczycy ze Wschodu dołączyli do UE. Ci z Południa uważali, że rozkwitają w strefie euro. W Atenach, Lizbonie i Madrycie istniało poczucie wyrównywania poziomów między europejskimi społeczeństwami, poczucie nowej, już nie tylko formalnej równości między narodami. Dziś ta iluzja została zdruzgotana" (Ash, 2012, s. 18-19).

Dziś wielu ekspertów i badaczy martwi się o przyszłość europejskiej integracji i Unii Europejskiej oraz proponuje różne sposoby ich ratowania. Chciałbym tutaj zwrócić uwagę na najnowsze rozprawy trzech kolejnych wybitnych znawców problematyki unijnej: Clausa Offe, Jana Zielonki i Giandomenico Majone, które wpisują się w intelektualną debatę na temat przyszłości integracji europejskiej i Unii Europejskiej. Proponują oni szersze i systemowe spojrzenie na niezbędne dla UE reformy, wykraczające poza propozycje kosmetycznych zmian o charakterze instytucjonalnym, które obecnie dominują w dyskursie publicznym (Offe, 2014; Majone, 2014). Ich zdaniem, dziś niezbędna jest zmiana metody integracji w Europie. Przy czym nie chodzi tylko o kosmetyczne zmiany w funkcjonowaniu systemu instytucjonalnego, jak na przykład połączenie funkcji przewodniczącego Rady i Komisji Europejskiej czy większą kontrolę Parlamentu Europejskiego nad Komisją, ale o systemową zmianę logiki funkcjonowania procesów integracyjnych w kierunku ich uelastycznienia. „Mniej integracji”, czy też jej uelastycznienie i lepsze dostosowanie do interesów poszczególnych państw i potrzeb ich obywateli, może oznaczać koniec Unii Europejskiej w obecnym kształcie, ale nie będzie to oznaczało końca integracji europejskiej. Rozważania tych trzech autorów dotyczą de facto źródeł i sposobów legitymizacji integracji europejskiej w przyszłości. I tak, C. Offe kładzie nacisk na problem wdrażania pokryzysowej strategii i mobilizację obywateli na rzecz europejskiego projektu (legitymizację na wejściu), a J. Zielonka i G. Majone koncentrują się na przywróceniu projektowi integracyjnemu legitymizacji na wyjściu, czyli reformie przeprowadzonej w taki sposób, 
by jej działania (skutki) były efektywne, a korzyści przeważały nad kosztami, a tym samym były widoczne i oczywiste dla obywateli. Trzeba - moim zdaniem - zmienić filozofię działania UE i sposób myślenia polityków o niej. Unia powinna być dla obywateli, a nie dla polityków, którzy ponoszą winę za jej błędy i mankamenty.

Kryzys finansowo-gospodarczy z lat 2008-2014 nie tylko ujawnił słabości, ale również pogłębił wszystkie deficyty i nieprawidłowości w funkcjonowaniu unijnego projektu i pokazał, że neoliberalna demokracja przeżywa dziś poważny kryzys. Mija już siódmy rok od jego wybuchu i wciąż nie ma odważnych, żeby obwieścić definitywny koniec tych turbulencji. Nasuwa się tu pytanie, co zmieniono w ciągu tych siedmiu lat w odpowiedzi na kryzys? Wydaje się, że najwięcej zrobiono w obszarze nadzorczym, gdzie m.in. powołano organy nadzoru makroostrożnościowego (niestety w Polsce wciąż jeszcze nie) i nastapił wysyp regulacji, określany mianem tsunami regulacyjnego. Jednym z nich jest docelowa unia gospodarczo-walutowa, której ideą jest jeszcze większa integracja krajów strefy euro. Projekt ten, na obecnym etapie wdrażania, nie rozwiązuje jednak wszystkich problemów strefy euro, która wciąż postrzegana jest głównie przez pryzmat wspólnej waluty i działań Europejskiego Banku Centralnego (EBC). A sytuacja poszczególnych gospodarek Eurolandu jest bardzo zróżnicowana, co istotnie utrudnia prowadzenie jednej polityki pieniężnej dobrej dla wszystkich krajów strefy euro. Zatem strefa euro jest wciąż w większym stopniu projektem politycznym niż ekonomicznym. Jest jeszcze wiele innych kwestii do rozwiązania, aby UE mogła efektywnie funkcjonować. Nasuwa się tutaj kolejne pytanie, czy jest możliwy następny kryzys? Wielu ekonomistów twierdzi, że tak, ale tak naprawdę nikt nie wie, kiedy on wybuchnie i gdzie. Nie jest wykluczone, że przyjdzie nam żyć w czasach permanentnego kryzysu, który będzie przyjmował różne oblicza, niekoniecznie drastycznie wpływające na życie wszystkich obywateli świata. Pamiętać należy także, że światy polityki i gospodarki, w tym rynków finansowych, tworzą system naczyń połączonych. I właśnie na tej płaszczyźnie powinna zostać wypracowana nowa strategiczna wizja dla UE (Zaleska, 2015, s. A14).

Sondaże mówią, że Europejczycy, w tym także Polacy, są niezadowoleni i zagubieni, że jest im dziś dużo trudniej wyobrazić sobie, jak Unia Europejska będzie wyglądała za dziesięć lat. Ponad 60\% Europejczyków obawia się, że ich dzieci będą miały gorsze życie niż oni sami (Mniej Europy, 2014, s. 3).

Już dzisiaj w UE mamy niemałą rzeszę poszkodowanych, wykluczonych i sfrustrowanych, którzy przyczyny swojego niepowodzenia upatrują w miałkości i sprzedajności elit politycznych i żądaja, by przestać ulegać dyktatowi kosmopolitycznych biurokratów i finansistów. Także, co wydaje się bardzo dziwnym, unijni przywódcy są zagubieni i bezradni wobec problemów, które utrudniają efektywne funkcjonowanie UE i prowadzenie skutecznej polityki wewnętrznej i zagranicznej. Pokazały to m.in. wybory do Parlamentu Europejskiego, które odbyły się w dniach 22-25 maja 2014 roku (Ostrowski, 2014, s. 58-60; Schulz, 2014, s. 41) oraz kryzys na Ukrainie i wojna rosyjsko-ukraińska (Madej, 2013, s. 24-271; Koziej, 2011, s. 76-84).

Jak pisze Ryszard Zięba: „Urzędujący politycy państw zachodnich starają się nie dostrzegać, bądź bagatelizują rozległość i głębię kryzysu wewnętrznego na Ukrainie. Nie widzą sił skrajnych i bagatelizują wewnętrzne przesłanki problemów tego państwa, a za całą kryzysową sytuację obwiniają tylko Rosję. Wspierają politycznie nowe 
władze w Kijowie i oferuja, obwarowane koniecznością przeprowadzenia drastycznych reform, obietnice pomocy ekonomicznej dla Europy. Kryzys postrzegają przede wszystkim w kategoriach międzynarodowych" (Zięba, 2014, s. 15).

W polityce UE kluczowe znaczenie mają decyzje o wciagnięciu Ukrainy do swojej strefy wpływów oraz potępianie i „karanie” Rosji za chęć niedopuszczenia do tego. 21 marca 2014 roku UE i Ukraina podpisały w Brukseli polityczną część umowy stowarzyszeniowej. To był symboliczny gest poparcia dla wschodniego sąsiada Unii i tymczasowych władz w Kijowie w trudnym dla Ukrainy czasie (po utracie Krymu). Następnie, aby nie dopuścić do bankructwa Ukrainy, jej nowe władze otrzymały wsparcie ekonomiczne od UE, Stanów Zjednoczonych i Międzynarodowego Funduszu Walutowego. A kilka tygodni po wyborach nowego prezydenta Ukrainy, którym został Petro Poroszenko, UE podpisała 27 czerwca 2014 roku z Ukrainą handlową część umowy stowarzyszeniowej. Nawiasem mówiąc, umowa ta nie przewiduje członkostwa Ukrainy w Unii, co uważam za poważny błąd. UE nie zaoferowała też wydatnej pomocy finansowej dla Ukrainy, natomiast z propozycją taką wystapiła Rosja. Dopiero po przejęciu władzy w Kijowie przez opozycję polityczną, a więc zwolenników integracji Ukrainy z UE oraz narastającej presji Rosji wspierającej oderwanie Krymu, Bruksela przedstawiła nowemu rządowi w Kijowie ofertę pomocy w wysokości około 11 mld euro. Unia Europejska, licząca 28 państw, mających często rozbieżne interesy nie była w stanie szybko nałożyć sankcji na Rosję, a bardziej dotkliwe restrykcje uzgodniła dopiero pod koniec lipca 2014 roku. Co jest istotne, nie dotyczą one odmowy importu gazu z Rosji, ani zawartych wcześniej kontraktów w innych dziedzinach, a niektóre państwa członkowskie Unii - jak już pisałem - krytykują politykę sankcji wobec Rosji, m.in. Węgry i Słowacja. Ujawniły się głębokie podziały wewnątrz UE na kraje, które zdecydowanie opowiedziały się za nałożeniem sankcji na Rosję, m.in. Polska, Litwa, Łotwa, Estonia i kraje, które kierując się względami praktycznymi, podchodziły do sankcji ostrożnie i z rozwaga, m.in. wspomniane wyżej Węgry i Słowacja, a także RFN, Hiszpania, Finlandia i Francja. Najgłośniej zaś za antyrosyjskimi sankcjami opowiadają się Polska i Litwa, które wręcz wpadły w histerię i straszą świat trzecią wojną światową (Rosja, 2015, http://polskanewswweek.pl/wojna-naukrainierosja-musi-zaatakować-polske-twierdzi-były-minister.artykuł.357321,I.html).

Prezydent Litwy, Dalia Grybauskaite oświadczyła, że „Rosja atakując Ukrainę, praktycznie zaatakowała Europę" (Robinson, Evans, 2014). Litwa wydała też specjalny przewodnik, w którym opisano, jakie należy podjąć działania w przypadku zaistnienia stanu wojny między Rosją i Litwą. Natomiast prezydent Bronisław Komorowski 1 marca 2014 roku oświadczył, że: „Po wystapieniu prezydenta Władimira Putina do rosyjskiej izby wyższej o zgodę na ewentualne użycie sił zbrojnych na terytorium całej Ukrainy, sprawa zrobiła się niesłychanie dramatyczna. [...] Możemy się czuć zagrożeni potencjalnym użyciem rosyjskich sił zbrojnych na terytorium sąsiedniej dla Polski Ukrainy". Co więcej, po raz pierwszy w historii Polska wystąpiła do Sojuszu Północnoatlantyckiego o zwołanie w trybie pilnym posiedzenia Rady Północnoatlantyckiej NATO, powołując się na artykuł 4 Traktatu Waszyngtońskiego. W myśl tego artykułu, każdy członek NATO może zażądać posiedzenia Rady,

${ }^{1}$ Patrz http://www.prezydent.pl/aktualnosci/wydarzenia/art,2822,polska-wystapila-o-zwołaniarady-polnocnoatlantyckiej.html. 
gdy uzna, że integralność terytorialna, polityczna niezależność czy niepodległość członka Sojuszu są zagrożone.

Uważam, że Polska zbyt aktywnie angażuje się w wydarzenia na Ukrainie, narażając się na retorsje ze strony Rosji, szczególnie dotkliwe dla polskiego rolnictwa. Wynika to z fundamentalnych założeń polityki zagranicznej Polski, w której traktuje się umacnianie niepodległości i zachodniego kursu w polityce zagranicznej Ukrainy jako jedną z podstawowych gwarancji, że Rosja nie powróci do polityki imperialnej. Rosję traktuje się w Polsce jako główne zagrożenie dla bezpieczeństwa narodowego, a konsekwencją tego jest polityka odpychania Rosji od Europy, odgradzania jej pasem buforowym w postaci prozachodnich państw na wschodniej granicy. Stanowi to współczesną realizację ,idei jagiellońskiej” oraz dawnych koncepcji Juliusza Mieroszewskiego i Jerzego Giedroycia, razem wziętych. Dlatego też Polska opowiada się za demokratyzacją Ukrainy i włączeniem jej do UE i NATO.

Tymczasem agresja Rosji na Ukrainę ujawniła całkowite fiasko powyższych kalkulacji i w ogóle fiasko polityki wschodniej UE, a szczególnie jej polityki wobec Rosji. Od początku swego istnienia UE w stosunkach z Rosją starała się zrealizować podstawowe cele: angażować Rosję w coraz ściślejsze kontakty z Europa, aby w ten sposób tworzące się współzależności doprowadziły do zmian w Rosji i jej konwergencji z UE. Wojna z Ukrainą pokazała, że Rosja potrafiła odwrócić tę zależność. Natomiast UE i jej główne mocarstwa nie potrafiły zdobyć się na stanowczą reakcję ze względu na interesy finansowo-gospodarcze oraz poddanie się rosyjskim interpretacjom odnoszącym się do ambicji i „praw” Moskwy oraz sensu relacji dwustronnych UE-Rosja (Kuźniar, 2014, s. 52).

Kryzys na Ukrainie pokazał to, o czym wiadomo już od dawna, a mianowicie, że UE jest podzielona i de facto nie ma wspólnej polityki zagranicznej i obrony, a inne jej polityki, w tym np. imigracyjna są mało skuteczne. Pokazał też, że Unią de facto rządzą Niemcy i Francja, które wzięły na swoje barki zadanie prowadzenia dialogu Moskwa-UE w sprawie Ukrainy. Trzeba jednak pamiętać, że Unia Europejska od momentu powstania, czyli od podpisania Traktatu z Maastricht starała się być mocarstwem normatywnym. Traktat ten istotę tożsamości UE sprowadzał do walki o utrzymanie pokoju i bezpieczeństwa oraz na rzecz rozwijania współpracy międzynarodowej zgodnie z aksjologią Unii oraz Kartą Narodów Zjednoczonych. Ponadto nadrzędnym celem UE stało się popieranie demokracji, rządów prawa, praw człowieka i podstawowych wolności. I w tym zakresie aktywność UE była niezrównana i przyniosła spore efekty, zwłaszcza w czterech obszarach: handlu, prawa człowieka, bezpieczeństwa, ochrony środowiska naturalnego i ziemskiego klimatu. Natomiast samodzielna, podmiotowa rola UE w stosunkach międzynarodowych nie była możliwa bez porzucenia amerykańskiej kurateli, która się wykształciła w czasach zimnej wojny. Problem stosunków transatlantyckich (euro-amerykańskich) był tym trudniejszy, że chodziło o relacje między dwoma częściami Zachodu, z których każda miała swoje powody do definiowania, jak powinno wyglądać przywództwo Zachodu w globalnym porządku międzynarodowym. Waszyngton dopuszczał większą rolę Europy, ale jedynie w sensie jej większego wkładu we wspólny wysiłek Sojuszu Atlantyckiego na rzecz bezpieczeństwa. Poza tym - jak pisze Roman Kuźniar - Waszyngton ,spoglądał na Europę, jak na gospodarczego rywala bez zdolności do przywództwa politycznego. 
Gdy od drugiej połowy lat 90. ubiegłego stulecia UE zaczęła zgłaszać aspiracje do większej niezależności, a wręcz globalnej roli zaczęły się kłopoty. Nasiliły się one w kontekście próby stworzenia przez UE wspólnej polityki bezpieczeństwa i obrony (od 1999 r.), pomyślanej jako polityczno-militarna zdolność do autonomicznego działania UE w sferze bezpieczeństwa. Spotkało się to z oporem, a nawet dywersją (poprzez zaprzyjaźnione kraje w Europie, które bardziej stawiały na sojusz z USA) Waszyngtonu" (Kuźniar, 2014, s. 53).

Po pierwszych sukcesach, tworzenie wspólnej polityki bezpieczeństwa i obrony, choć zgodnie z przyjętą w 2003 roku strategią bezpieczeństwa UE miała być zdolna do współodpowiedzialności za globalne bezpieczeństwo i budowę lepszego świata, uległo wyhamowaniu. Złożyło się na to wiele przyczyn. Kwestie wiążące się z wykorzystaniem zasobów wojskowych, a do pewnego stopnia także pozamilitarnych państw członkowskich do budowy międzynarodowej stabilności i bezpieczeństwa - z jednej bowiem strony dotykają sfer tradycyjnie uznawanych za jądro suwerenności państw i ich najbardziej fundamentalnych interesów, z drugiej zaś wiążą się z dużymi nakładami finansowymi. To powoduje, że stosunkowo słabo poddają się one procesom integracyjnym, zachowując w znacznej mierze tradycyjny, międzyrządowy kształt. Znalazło to wyraz choćby w instytucjonalnym kształcie Wspólnej (dawnej Europejskiej) Polityki Bezpieczeństwa i Obrony UE (WPBiO) oraz obowiązujących w jej ramach procesach decyzyjnych, wciąż wymagających osiągnięcia konsensusu między wszystkimi państwami uczestniczącymi. Wydaje mi się, że jest to jedna z głównych przyczyn relatywnie ograniczonego, zwłaszcza na tle pozostałych dziedzin integracji europejskiej, rozwoju współpracy w sferze obronności w ramach Unii Europejskiej. Podczas wojny z Irakiem, Stanom Zjednoczonym udało się podzielić UE i de facto powstrzymać jej starania o strategiczną autonomię i podmiotowość (Świątek, 2011; Zarychta, 2014). Reszty dokonał kryzys finansowo-gospodarczy od 2008 roku, a także sprzeciw lub brak zainteresowania różnych państw unijnych. Kryzys ten osłabił Francję, która przestała być pełnowartościowym partnerem RFN i w jeszcze większym stopniu Włochy, a Londyn ogłosił zamiar zmniejszenia swej obecności w UE i wyznaczył na 2016 rok referendum w sprawie dalszej obecności Wielkiej Brytanii w strukturach Unii Europejskiej. Tak osłabione Niemcy nie potrafiły zapewnić UE politycznego przywództwa. Gdy więc w okresie rządów Baracka Obamy Europa otrzymała od zwracającego się ku Azji Waszyngtonu zielone światło do autonomicznych działań w sprawach bezpieczeństwa, to podzieleni i nieskorzy do wysiłku zbrojnego Europejczycy, stracili zapał i nie skorzystali z tej okazji, aby w ten sposób wzmocnić UE i jej rolę w budowie nowego porządku międzynarodowego. W konsekwencji Europa dziś nie stanowi wielkiej niezależnej potęgi w skali globalnej i niewielu spodziewa się, że Unia Europejska w najbliższym czasie osiagnie rangę politycznie istotnego globalnego gracza, a przodująca rola Stanów Zjednoczonych wydaje się niepewna (Kuźniar, 2011; Brzeziński, 2013).

UE można dziś zarzucić jeszcze wiele grzechów, takich m.in. jak narastające tendencje separatystyczne, z którymi sobie nie radzi w Szkocji, Katalonii, Kraju Basków, na Korsyce i w Południowym Tyrolu. Co więcej, Unia jest oderwana od obywateli, a obywatele nie utożsamiają się z UE. Sprzyja to narastaniu eurosceptycyzmu i tendencji renacjonalizacyjnych, co wykorzystują partie populistyczne i skrajnie nacjona- 
listyczne do walki o władzę i przeciwko poszerzaniu Unii oraz napływowi imigrantów do UE. Na przykład Marine Le Pen, szefowa Frontu Narodowego we Francji, który cieszy się coraz większym poparciem społecznym nie kryje, że dąży do zniszczenia UE i do oczyszczenia Francji i całej Europy z imigrantów (Grosse, 2014, s. A11).

Z drugiej zaś strony, ta sama Unia jest nadal atrakcyjną „ziemią obiecaną” dla setek tysięcy imigrantów z całego świata. Wciąż ma ogromną siłę przyciągania, o czym świadczy kolejka państw zabiegających o członkostwo w tym specyficznym związku demokratycznych i suwerennych państw. Dziś trudno sobie wyobrazić Europę i świat bez Unii Europejskiej. Dlatego też, summa summarum, jak pisze Timothy Garton Ash: „Strach przed upadkiem, logika konieczności przypominająca logikę Moneta, siła inercji - wszystko to pozwoli być może europejskiemu przedsięwzięciu [czyli UE - J. M. F.] trwać nadal, ale nie stworzy dynamicznej, otwartej na zewnątrz Unii, która cieszy się poparciem swoich obywateli. Bez jakichś nowych sił, bez pozytywnej mobilizacji elit i społeczeństw Unia wprawdzie przetrwa jako skomplikowana układanka traktatów i instytucji, ale efektywność jej działań i rzeczywiste znaczenie będą stopniowo spadać tak jak niegdyś znaczenie Świętego Cesarstwa Rzymskiego" (Ash, 2012, s. 19).

\section{III}

Rok 2014, a zwłaszcza wydarzenia na Ukrainie, Bliskim Wschodzie i w Afryce Północnej dobitnie uświadomiły Europie, że koniec historii, w który uwierzono po upadku muru berlińskiego i rozpadzie ZSRR, był złudzeniem. Triumfalizm i nadzieja na „wieczny pokój” skończyły się, a wiara w stopniowa, lecz nieuchronną demokratyzację kolejnych państw i społeczeństw zostały mocno nadwątlone. W świetle dramatycznych wydarzeń w Kijowie, na Krymie i w Donbasie, a także w Syrii, Iraku i Paryżu, wyraźnie uwidoczniły się też liczne słabości Unii Europejskiej oraz uległ osłabieniu jej prestiż na świecie. Jedenaście lat po wielkim rozszerzeniu UE na Wschód, pokój i bezpieczeństwo Europy i świata są dziś poważnie zagrożone. Niepokój budzą dziś zwłaszcza takie zjawiska i procesy, jak: podważanie wiarygodności porozumień rozbrojeniowych, w tym dotyczących nieproliferacji broni masowego rażenia, utrzymywanie się reżimów autorytarnych i postaw konfrontacyjnych, nieposzanowanie zasad prawa międzynarodowego, standardów demokratycznych, praw człowieka, mniejszości etnicznych i religijnych, nasilający się międzynarodowy terroryzm i zorganizowana przestępczość. Wobec tak poważnych zagrożeń, kraje Europy Środkowo-Wschodniej muszą współpracować z NATO i UE oraz umacniać swoje bezpieczeństwo wespół z innymi państwami, należącymi do systemu euroatlantyckiego. Nie ulega wątpliwości, że dalszy rozwój WPBiO oraz umacnianie systemu euroatlantyckiego leżą w interesie UE, Europy, a szczególnie państw Europy Środkowo-Wschodniej. Niezbędne jest też dążenie do rozwijania w ramach Unii Europejskiej współpracy w zakresie urzeczywistniania Przestrzeni Wolności, Bezpieczeństwa i Sprawiedliwości, w szczególności w obszarze wymiaru sprawiedliwości i spraw wewnętrznych. Polska - jak pokazuje to miniona dekada - postrzegała i nadal postrzega integrację z Unią Europejską nie tylko w kategoriach czysto ekonomicznych - konkretnych zysków finansowo- 
gospodarczych, jakie osiąga dzięki członkostwu, choć niewątpliwie fundusze, które zaczęły płynąc do naszego kraju jeszcze przed 2004 r. i po akcesji do UE w dużym stopniu wsparły wysiłki modernizacyjne państwa (Wpływ członkostwa, 2014; Kałużyńska, Karbownik, 2014).

Ważniejszy, z punktu widzenia strategicznych, długofalowych interesów naszego państwa, jest aspekt bezpieczeństwa narodowego, a więc szerszy wymiar zaangażowania Polski w procesy integracyjne w Europie i w umacnianiu pozycji UE na arenie międzynarodowej. Dlatego też Polska po 2004 roku konsekwentnie opowiada się za poszerzaniem i pogłębianiem Unii Europejskiej oraz umacnianiem jej współpracy z NATO i Stanami Zjednoczonymi, które są naszym najważniejszym pozaeuropejskim partnerem. Z perspektywy Warszawy, rozszerzenie UE nie jest więc tylko i wyłącznie technicznym oraz politycznym procesem przyjmowania do UE kolejnych (nowych) państw, ale jest przede wszystkim ważnym instrumentem, dzięki któremu Europa może zachować i umacniać swoją pozycję w świecie.

Polska była, jest i powinna być nadal orędownikiem obiektywnego procesu rozszerzenia, który nie będzie zakładnikiem partykularnych interesów państw członkowskich, gdyż tendencje, które dziś dotyczą głównie rozszerzenia, a więc „,nacjonalizacja” tego procesu, bez wattpienia zostaną przeniesione również na inne obszary europejskiej polityki, a nawet już są przenoszone, na przykład odnośnie polityki migracyjnej. Polska, jako liczące się dziś państwo członkowskie UE, powinna nadal pozycjonować się jako obrońca instytucji wspólnotowych, stojących na straży wypadkowej interesu całej Wspólnoty. Takie są bowiem doświadczenia po jedenastu latach naszej obecności w Unii Europejskiej. Co więcej, choć dziś perspektywa akcesji dużych państw, na przykład Turcji i Ukrainy, a także innych państw proradzieckich może wydawać się mało realna czy wręcz nieprawdopodobna, Polska powinna pozostawać orędownikiem członkostwa tych państw w Unii Europejskiej, i szerzej, w strukturach euroatlantyckich, tak ze względów geopolitycznych, jak i geoekonomicznych. Innej bowiem alternatywy - poza rozpadem - dla UE nie ma. Chciałbym tutaj raz jeszcze podkreślić, że:

1. Świat dziś wyraźnie ewoluuje w kierunku multipolarnym i wielocywilizacyjnym, ale rola Europy i w ogóle Zachodu na arenie międzynarodowej maleje. Zachód traci swoje gospodarcze, polityczne, demograficzne i moralne podstawy, a wraz z tym przestaje być wzorcem rozwojowym dla świata.

2. Unia Europejska, mimo wielu problemów ma jednak potencjały, aby mogła i powinna stać się aktywnym podmiotem w systemie euroatlantyckim i w nowym ładzie globalnym.

3. Świat, którego bezpieczeństwo i pokój są dziś poważnie zagrożone, potrzebuje efektywnego systemu euroatlantyckiego, a więc z silną UE, silnymi Stanami Zjednoczonymi i silnym NATO.

4. Unia Europejska musi się sukcesywnie pogłębiać i poszerzać oraz doskonalić swój system polityczny i gospodarczy (być może w kierunku federalistycznym), aby stać się graczem światowym, tak w aspekcie geoekonomicznym, jak i geopolitycznym.

5. Polska, jako istotny podmiot współczesnych stosunków międzynarodowych, powinna wykorzystać swoje doświadczenia i obecność w Unii Europejskiej do dal- 
szego wzmocnienia swojej pozycji w regionie, a także w Europie i na świecie oraz zintensyfikować dialog i współpracę ze Stanami Zjednoczonymi i państwami należącymi do grupy BRIC, w tym także z Rosją.

\section{Zakończenie}

Kryzys ukraiński pokazał z całą moca, że pozimnowojenny porządek międzynarodowy wymaga przewartościowania, a nawet poważnych korekt, tak w aspekcie teoretycznym, jak i praktycznym. Dziś znowu triumfuje mocarstwowa Realpolitik, a unijna polityka soft power ponosi porażki. Wydarzenia na Ukrainie pokazują, jak bezradna jest UE wobec agresywnej polityki Rosji. Wobec interwencji militarnej u swych bram stawia na tradycyjne środki dyplomatyczne - oświadczenia, konsultacje i sankcje, które są nieskuteczne. UE dziś, to zbiurokratyzowana do granic wytrzymałości machina, która działa nieefektywnie i bez klarownej strategii. Tymczasem przemoc (siła wojskowa) nadal stanowi o istocie władzy i potędze. Aby UE, niewątpliwie gospodarcza potęga, przestała być politycznym karłem, powinna to zrozumieć. Tylko dzięki wspólnemu budowaniu potencjału siły, w tym także wojskowej, będzie w stanie umacniać europejskie standardy w swoim otoczeniu i na świecie. Godzi się to robić jedynie w imię zasad liberalnej demokracji: wolności, praw człowieka i państwa prawa. Tu jednak tkwi paradoks. Te zasady bowiem każą jednocześnie potępiać użycie siły, w tym wojnę, a jednocześnie trzeba być do wojny gotowym. Żadna próba budowy europejskiej siły militarnej jak dotąd się nie powiodła, ale w końcu musi się to udać, jeśli UE ma być istotną częścią systemu euroatlantyckiego i chce współtworzyć nowy multipolarny ład globalny oraz nie dopuścić do nowej zimnej wojny (Kramer, 2015, s. 7-13).

Jest to niezbędne, gdyż Zachód, który po kryzysie finansowo-gospodarczym z lat 2008-2014 i prestiżowych porażkach dyplomatycznych, a w przypadku Stanów Zjednoczonych także wojskowych (w Iraku i Afganistanie) wyraźnie pogubił się. Nie mogąc się odnaleźć w dokonującej się przemianie ładu globalnego, a pozostając w defensywie wobec grupy BRIC, obrał Rosję za swego rywala, którego próbuje zepchnąć na peryferie światowej polityki. Tymczasem Rosja pod rządami W. Putina staje się coraz silniejsza i aktywnie włącza się do globalnej rozgrywki. Dlatego też należy z nią rozmawiać, a nie izolować ją na arenie międzynarodowej, bo to zmusza Rosję do działań agresywnych, czego przykładem jest jej wojna z Ukraina, co może doprowadzić do nowej zimnej wojny w stosunkach międzynarodowych, lub do trzeciej wojny światowej. Normalizacja stosunków między Zachodem i Rosją jest też koniecznym warunkiem do wyprowadzenia Ukrainy z głębokiego kryzysu, która powinna mieć prawo do swobodnego wyboru swoich ekonomicznych i politycznych partnerów (Mearsheimer, 2014, s. 1-16; Cohen, 2014, s. 3; Macierewicz, 2015, s. 8).

Dziś prezydent Władimir Putin wręcz ostentacyjnie demonstruje, że UE się nie obawia, bo Bruksela nie wprowadzi nowych sankcji. Rosja, zamiast wycofać się z Krymu, eskaluje wsparcie dla separatystów i łamie wcześniejsze uzgodnienia międzynarodowe dotyczące Ukrainy. Moskwa nie przerwała dostaw broni dla separatystów i nadal koncentruje swoje wojska na granicy z Ukrainą. Na Ukrainie zaś narasta rozgorycze- 
nie postawą Zachodu, a zwłaszcza UE. Po zajęciu Krymu przez Putina Zachód ostrzegał, że powtórzenie tego scenariusza przeciwko Ukrainie „kontynentalnej” spowoduje nieobliczalne konsekwencje dla Rosji. I co? Nic! Przeciwko Ukrainie toczy się dziś regularna wojna, a jej stroną są nie tylko separatyści, lecz państwo rosyjskie. Brak zachodniej interwencji i pomocy sprawiaja, że Rosjanie czują się na ukraińskim gruncie coraz pewniej i dokonują coraz śmielszych ruchów (Macierewicz, 2015, s. 14-16).

Rola UE w budowaniu relacji dwustronnych z Ukrainą jest szczególnie istotna w sytuacjach krytycznych. Wszelkie gesty, które mogą być uznane na Ukrainie za skierowane przeciwko interesom obywateli Ukrainy, są wykorzystywane przez przeciwników kierunku europejskiego do wspierania współpracy z Rosją. Od początku walk na wschodzie Ukrainy zginęło ponad pięć tysięcy osób, a kolejnych kilka tysięcy zostało rannych. Do tych liczb trzeba też dodać 298 nieszczęsnych ofiar malezyjskiego boeinga 777, zestrzelonego 17 lipca 2014 roku nad Ukrainą przez separatystów samozwańczej Donieckiej Republiki Ludowej, szkolonych i zbrojonych przez Rosję, która nie chce, aby Ukraina była suwerenna i demokratyczna (Ukraina, 2015, s. 18).

Nie ulega wątpliwości, że jest to efekt bezwzględnej, cynicznej i imperialnej polityki prezydenta Władimira Putina, która zagraża całemu światu. Dąży on bowiem do renesansu rosyjskiego imperium i zapewnienia mu strategicznej pozycji w kształtującym się dziś multipolarnym ładzie globalnym. W tym też celu Rosja wraca także na Kaukaz Południowy: Abchazja i Osetia Południowa są już de facto częścią imperium Putina; Azerbejdżan wykonuje zwrot w stronę Moskwy, która kusi go odzyskaniem Górskiego Karabachu, a Armenia już dawno jest mu podporządkowana. Nawet w Gruzji dziś słychać coraz więcej głosów, że integracja z północnym sąsiadem jest rozsądna. Notabene, Kaukaz, mimo że tak różny od Rosji oraz mimo problemów, jakie nieustannie generuje, jest w oczach Rosjan immanentną częścią „rosyjskiego świata” (Falkowski, 2015, s. 70-76). Tych faktów jednak wiele państw należących do UE - z Niemcami i Francją na czele - nie chce brać pod uwagę (Czech, 2014, s. 8; Bielecki, 2014, s. 12; Zawadzki, 2014, s. 2).

Unia Europejska przyzwyczajona do stosowania soft power i zmęczona trawiącymi ją kryzysami, nie ma ani determinacji, ani świadomości rosnącego zagrożenia i ogląda się na Stany Zjednoczone, które po klęsce w Afganistanie i Iraku też nie mają ochoty na angażowanie się w obronie demokracji na Ukrainie. W efekcie tego, eskalacja przemocy ze strony Rosji, w tym zwłaszcza jednostronne zajęcie Krymu nie spotkała się z odpowiednio twardą odpowiedzią Zachodu. Świadczy to - moim zdaniem - o wyczerpaniu Stanów Zjednoczonych i Unii Europejskiej długotrwałym kryzysem finansowo-gospodarczym i pokazuje, że sojusz euroatlantycki dziś również przeżywa głęboki kryzys i traci swoją strategiczną moc, co rozzuchwala Rosję. Putin stosuje wiele różnych, choć wzajemnie ze sobą powiązanych, instrumentów. Tymczasem z Rosją rządzoną autorytarnie przez Władimira Putina i z nim samym trzeba jednak rozmawiać, w ostateczności także przy użyciu siły, a nie tylko siły argumentów, których Rosja nie uznaje. Ukraina zaś, bez zachodniej pomocy militarnej i gospodarczej, wojny z Rosją nie wygra. Trzeba więc Rosję jak najszybciej zawrócić na właściwą drogę, uciekając się do różnych środków - dyplomatycznych, gospodarczych i wojskowych.

Wydaje mi się, że nadchodzi już moment, w którym także Rosji zacznie zależeć na znormalizowaniu stosunków z Zachodem, w tym również z Unią Europejską. Władi- 
mir Putin, wdając się w konflikt zbrojny z Ukrainą, przeliczył się i zaczyna chyba to dziś rozumieć. Musi też podjać działania naprawcze w gospodarce i przeprowadzić głębokie reformy aparatu państwa, ustroju federalnego, w ogóle rosyjskiego ustroju politycznego, a szczególnie wymiaru sprawiedliwości i organów ścigania, a więc będzie bardziej skłonny do zawarcia porozumienia z Ukrainą i Zachodem. Innej alternatywy, poza rozpadem Rosji i utratą władzy - Putin nie ma. Chyba, że zdecyduje się na rozwiązania siłowe i na wojnę $\mathrm{z}$ całym Zachodem, której i tak by nie wygrał. Zatem Zachód, również UE i NATO, cały sojusz euroatlantycki, powinien przygotować nową strategię współpracy z Rosją i pozostałymi państwami Europy Wschodniej, której głównym celem będzie umocnienie pokoju i bezpieczeństwa w Europie.

\section{Bibliografia}

Ash T. G. (2012), Kryzys Europy. Czyli jak Unia powstata i dlaczego się rozpada, „Przegląd Polityczny", nr 115/116.

Bielecki T. (2014), Co myśli Putin o Ukrainie, „Gazeta Wyborcza”, 11.07.2014.

Bielecki T. (2014), Europa podstarzata i przyttumiona, „Gazeta Wyborcza”, 26.11.2014.

Borkowski R. (2006), Terroryzm ponowoczesny. Studium z antropologii polityki, Toruń.

Brzeziński Z. (2013), Strategiczna wizja. Ameryka a kryzys globalnej potęi, Kraków.

Cohen S. F. (2014), Patriotic Heresy vs. the New Cold War: Fallacies of US Policy May by Leading to War Wit Russia, „The Nation”, 15.09.2014.

Czech M. (2014), Wojna znów wisi na włosku, „Gazeta Wyborcza”, 15.07.2014.

Czech M. (2015), Kreml straszy świat wojna, „Gazeta Wyborcza”, 9.03.2015.

Danecki J. (2002), Podstawowe wiadomości o islamie, t. I i II, Warszawa.

Dziekan M. (2007), Cywilizacja islamu w Azji i Afryce, Warszawa.

Dziekan M. (2008), Dzieje kultury arabskiej, Warszawa.

Falkowski M. (2015), Imperium kontratakuje, „Nowa Europa Wschodnia”, nr 2.

Fiszer J. M. (2013), Terroryzm jako zagrożenie dla bezpieczeństwa euroatlantyckiego i nowego ładu międzynarodowego, w: System euroatlantycki w wielobiegunowym tadzie międzynarodowym, red. J. M. Fiszer, P. Olszewski, Warszawa.

Grosse T. G. (2014), W oczekiwaniu na rewolucję, „Rzeczpospolita”, 22.07.2014.

Jordan M. (2014), Islam. Historia religii i kultury, Warszawa.

Kałużyńska M., Karbownik P., Burkiewicz W., Janiak K., Jatczak M. (2014), Polskie 10 lat w Unii. Raport, Ministerstwo Spraw Zagranicznych, Warszawa.

Koszel B. (2012), Mocarstwowe aspiracje Niemiec w Europie XXI wieku: realia i perspektywy (Raport z badań), „IŻ Policy Papers”, nr 6.

Koziej S. (2011), Potrzeba nowelizacji strategii bezpieczeństwa Unii Europejskiej, „Bezpieczeństwo Narodowe", nr IV (20).

Koziej S. (2006), Między piektem a rajem: szare bezpieczeństwo na progu XXI wieku, Toruń.

Kramer D. J. (2015), Doubletake: A New Cold War?, „New Eastern Europe”, no. 2 (XVI).

Krawczyk R. (2009), Islam. Świat thumionych emocji, Łódź.

Kuźniar R. (2011), Kryzys 2008 a pozycja międzynarodowa Zachodu, Warszawa.

Lewandowski Z. (2008), Islam. Nurty, odtamy, sekty, Warszawa.

Maciejewicz P. (2015), Ukraina - terapia szokowa, „Gazeta Wyborcza”, 14-15.03.2015. 
Majone G. (2014), Rethinking the Union of Europe Post-Crisis: has Integration Gone Too Far?, Cambridge.

Madej M. (2013), Wplyw udziału w Wspólnej Polityce Bezpieczeństwa i Obrony na polska politykę bezpieczeństwa, w: Polska w Unii Europejskiej. Bilans dekady, red. F. Tereszkiewicz, Warszawa.

Mearsheimer J. (1993), Why the Ukraine Crisis Is the West's Fault: The Liberal Delusions That Provoked Putin, „Foreign Affairs”, nr 5, t. 93.

Mendel K. G. (2010), Islam, Warszawa.

Mniej Europy, więcej Europy. Z Iwanem Kreszczewem rozmawia Adam Leszczyński, „Gazeta Wyborcza”, 31.05-1.06.2014.

Moszyński P. (2014), Papież chwali i gani Europe, „Gazeta Wyborcza”, 26.11.2014.

Ostrowski M. (2014), Koniec marzeń, „Polityka”, 4-10.06.2014.

Offe C. (2015), Europe Entrapped, Cambridge.

Sardar Z., Davies M. W. (2005), Islam, Warszawa.

Schulz M. (2014), Skrępowany OLBRZYM. Ostatnia szansa Europy, Warszawa.

Siła rzadzi światem. Z Richardem Pipesem rozmawia Michat Potocki, „Dziennik Gazeta Prawna”, 20-22.03.2015.

Świątek H. (2011), Wojna z Irakiem w 2003roku. Główne przyczyny, Warszawa.

Tibi B. (1997), Fundamentalizm religijny, Warszawa.

Ukraina potrzebuje pieniędzy, nie broni. Z prof. Adamem D. Rotfeldem rozmawia Bartosz T. Wieleński, „Gazeta Wyborcza”, 14-15.02.2015.

Weiler J. H. (2007), Europa końca wieku: czy nowe szaty maja swojego cesarza?, „Nowa Europa”, nr I(5).

Wpływ członkostwa Polski w Unii Europejskiej i realizowanej polityki spójności na rozwój kraju (2014), Warszawa.

Zaleska M. (2015), Kryzysowe przemyślenia, „Dziennik Gazeta Prawna”, 11.03.2015.

Zarychta S. (2014), Doktryny i strategie NATO 1949-2013, Warszawa.

Zawadzki M. (2014), To Europa może zatrzymać Putina, „Gazeta Wyborcza”, 19-20.07.2014.

Zielonka J. (2014), Is the EU doomed?, Cambridge.

Zięba R. (2014), Międzynarodowe implikacje kryzysu ukraińskiego, „Stosunki Międzynarodowe - International Relations", nr 2, t. 50.

\section{Streszczenie}

Nie ulega wątpliwości, że Unia Europejska, będąca efektem europejskiej integracji jest w historii stosunków międzynarodowych bezprecedensowym podmiotem. Jest symbolem nowej, jednoczącej się Europy, która po negatywnych doświadczeniach postanowiła stać się kontynentem bezpiecznym, a więc wyeliminować raz na zawsze wojnę z życia jej państw i narodów. Niestety, idei „wiecznego pokoju”, o czym marzyło wielu polityków i filozofów do dnia dzisiejszego nie udało się do końca zmaterializować. Co więcej, niedawne wojny na Bałkanach i obecna wojna rosyjsko-ukraińska wciąż uniemożliwiają wprowadzenie tej idei do stosunków międzynarodowych w Europie.

Celem niniejszego artykułu jest pokazanie Unii Europejskiej dziś, po dziesięciu latach od poszerzenia w 2004 roku jej składu o kolejne dziesięć państw, w tym aż osiem z byłego bloku wschodniego. Artykuł ten ukazuje atuty i słabości UE, która choć uległa dzięki temu poszerzeniu na Wschód daleko idącemu wzmocnieniu, to jednak dziś nie radzi sobie $\mathrm{z}$ wieloma proble- 
mami ekonomicznymi, politycznymi, społecznymi i międzynarodowymi. W artykule próbuję dać odpowiedź na wiele pytań dotyczących współczesnej UE, m.in. dlaczego tak się dzieje i jakie są tego przyczyny oraz jakie dla niej są perspektywy w XXI wieku. Tezą głównąjest tutaj stwierdzenie, że UE wymaga kapitalnego remontu tak, aby mogła dalej rozwijać się i być motorem integracji Europy. Jeśli zaś to nie nastapi, to UE zacznie się rozpadać i w końcu rozpadnie się lub stanie się co najwyżej strefą wolnego handlu.

Słowa kluczowe: Unia Europejska, integracja, kryzys finansowy, ład międzynarodowy, Zachód, Rosja, Ukraina

\title{
The European Union today and its uncertain future. Part II
}

\begin{abstract}
Summary
There is no doubt that the European Union, which is the result of European integration is unprecedented subject in the history of international relations. It is a symbol of a new, united Europe, which after negative experiences decided to become a safe continent, and therefore eliminate once and for all war of life of its states and nations. Unfortunately, the idea of "eternal peace", which many politicians and philosophers dreamed about failed to fully materialize to this day. Moreover, the recent war in the Balkans and the current Russian-Ukrainian war still make this idea impossible to impose into the international relations in Europe.

The purpose of this article is to present the European Union today, ten years after its enlargement of further ten countries, including eight from the former Eastern bloc in 2004. This article shows the strengths and weaknesses of the EU, which, although through far enlarge to the East strengthened itself, still cannot cope with many economic, political, social and international problems. I try to answer in this text on many questions relating today's EU: why is this happening, what are the reasons for it and what are the prospects for the EU in the XXI century. The thesis main assertion here is that the EU needs overhauling, so it can continue to grow and be an engine of European integration. But if this does not happen, the EU will begin to crumble and eventually disintegrate or become no more than a free trade zone.
\end{abstract}

Key words: European Union, integration, financial crisis, international order, West, Russian, Ukraine 